\title{
Penerapan Tanggung Jawab Sosial Perbankan Syariah Milik Negara dengan Indeks Islamic Social Reporting
}

\author{
Muhamad Fauzi ${ }^{1}$, Wahyu Haris Akbarudin ${ }^{2}$, Iwan E. Darmasetiawan ${ }^{3}$, Ahmad Darussalam ${ }^{4}$ \\ 1,2,3,4 Magister Keuangan Syariah ITB Ahmad Dahlan Jakarta \\ *Email Korespondensi: ojixzy1979@gmail.com
}

\begin{abstract}
The issue of merging Islamic banking in Indonesia is important as an effort to increase market share and competitiveness, while the social responsibility practice of Islamic banking in Indonesia is in the lowest rank among Southeast Asian Muslim countries. Are two things important for public confidence in the Islamic banking industry in Indonesia, which has a less informative predicate and not implementing social activities performance. Purpose this paper to explaine implementation of social responsibility for state-owned Islamic banking. Qualitative descriptive research method using Ethnographic Content Analysis (ECA) technique from annual reports with purposive sampling technique are BNI Syariah, Bank Syariah Mandiri and BRI Syariah at 20142018 using the Islamic Social Reporting (ISR) Index by AAOIFI. The results showed are funding and investment with (68.89\%), products and services (91.11\%), employees (68.72\%), society (75.15\%), environment (46.67\%), and corporate governance (88.44\%), a whole revealed that the social responsibility of state-owned Islamic banking (73.16\%). Conclusion predicate of implementing social responsibility is very informative (products and services as well as corporate governance), informative (funding and investment, employees, community) and less informative (environment) so that the implementation of social responsibility in state-owned Islamic banking is informative in the order of BSM, BNI Syariah and BRI Syariah.
\end{abstract}

Keywords: social responsibility, Islamic banks, state-owned, ISR Index

Saran sitasi: Fauzi, M., Akbarudin, W. H., Darmasetiawan, I. E., \& Darussalam, A. (2020). Penerapan Tanggung Jawab Sosial Perbankan Syariah Milik Negara dengan Indeks Islamic Social Reporting. Jurnal Ilmiah Ekonomi Islam, 6(03), 488-500. doi: http://dx.doi.org/10.29040/jiei.v6i3.1342

DOI: http://dx.doi.org/10.29040/jiei.v6i3.1342

\section{PENDAHULUAN}

Dalam pengembangan produk dan jasa, suatu perusahaan selain mencari keuntungan finansial dituntut juga memberikan keuntungan sosial sebagai bentuk respon terhadap fakta dilingkungan bisnisnya, hal ini menunjukkan indikasi pentingnya pembangunan berkelanjutan (suistainable development) yang dimaknai sebagai rangkaian yang tidak dapat melepaskan tanggungjawab dalam bentuk papun. Sebagaima yang dikatakan Budimanta (2004) pembangunan berkelanjutan sebagai kegiatan secara sistematis dan terencana untuk meningkatan kesejahteraan, kualitas kehidupan dan lingkungan umat manusia sedangkan Diesendorf (2010) berpendapat bahwa keberlanjutan adalah tujuan atau titik akhir dari suatu proses yang disebut pembangunan berkelanjutan.
Bagian terpenting pembangunan berkelanjutan adanya tanggungjawab sosial yang dimiliki oleh perusahaan, dimana fakta tersebut memberikan manfaat jangka panjang seperti peningkatan nilai perusahaan (saham), menjaga legitimasi perusahaan, meningkatkan penjualan dan membuat masyarakat ikut menjaga eksistensi dari perusahaan (Ang \& Marsella, 2015). Hadirnya tanggungjawab sosial pada perusahaan moderen memberikan arti penting bagi peran dan kontribusinya bagi sesama dilingkungannya atau istilah lainnya corporate social responsibility (CSR), menurut Brusseau (2012) tanggung jawab sosial perusahaan sebagai teori khusus menegaskan bahwa korporasi adalah entitas dengan kewajiban ekonomi, hukum, etika, dan filantropi kemudian ditegaskan (Quazi et al, 2015) merupakan pelaporan sosial yang kritis bagi semua perusahaan untuk 


\section{Jurnal Ilmiah Ekonomi Islam, 6(03), 2020, 489}

meningkatkan kesadaran publik, dampak perusahaan terhadap masyarakat dan lingkungan.

Dalam etika bisnis peran penting dari perusahaan yang berbasis Islam yang tidak hanya beorientasi pada manfaat perusahaan melainkan manfaat sosial sehingga hadirnya prinsip Islam dalam etika bisnis Islami (Rice, 1999) mengajak untuk melihat kenyataan kehidupan sehari-hari melupakan prinsip etika dan tradisi Islam itu sendiri sehingga seorang menajer harus mampu mengembangkan dan menerapkan filosofi bisnis yang seimbang dan mengkombinasikan antara perusahaan dengan aspek sosialnya.

Begitupun perbankan syariah dalam aktivitas dan entitas bisnisnya selain mengacu pada ketentuan syariah serta mencapai keuntungan yang berbasis syariah dituntut memberikan tanggungjawab sosialnya kepada lingkungan masyarakat sebagai wujud amalan kebajikan sebagaimana dalam AlQur'an (QS. Ali Imran:134), dimana tanggungjawab sosial perusahaan Islami atau Islamic corporate social resposibility (ICSR) berasal dari prinsip Al-Qur'an dengan tiga besar yaitu wakil umat manusia di bumi, pertanggungjawaban Ilahi dan kewajiban umat manusia untuk memerintahkan atau menjalankan yang baik dan melarang atau menjauhi kejahatan (Alshammary, 2014).

Sebagian besar masyarakat di Indonesia merupakan Muslim yang memiliki hak untuk mengetahui berbagai informasi kegiatan organisasi dan perusahaan yang dilakukan untuk melihat apakah yang telah sesuai dengan koridor syariah dan mencapai tujuan yang ditetapkan, sebagaimana pendapat (Hadinata, 2018), hal tersebut menjelaskan secara keseluruhan bahwa tingkat pengungkapkan kinerja sosial perbankan syariah di Asia Tenggara masih berada di posisi kurang informatif dengan skor sebesar 55,35\% (Maesya'bani et al, 2019). Dimana Indonesia secara substansial mempromosikan sistem perbankan Islam yang tergolong negara berkembang dan Islam adalah agama dominan dengan total populasi Muslimnya 21\% dari populasi Muslim dunia (PewResearch Center, 2009).

Perbankan syariah di Indonesia berada pada tingkat pengungkapan yang lebih rendah dalam dimensi pasar dan komunitas, dimana selama lima tahun terakhir menyajikan tingkat pelaporan tanggungjawab sosial yang paling rendah dalam pengungkapan CSR ditempat kerja dan sejak tahun 2010 hampir tidak pernah menindaklanjuti dan tidak berhasil meminimalisir kesenjangan pengungkapan CSR (Amran et al, 2017), kemudian hal senada diungkapkan (Arif \& Zaki, 2017) dimana informasi sosial berdasarkan Islamic Social Responsibility (ISR) indeks masih belum optimal dengan rata-rata sebesar 46,39\% dimana masih dibawah 50\%, (Hadinata, 2018) menyebutkan bahwa perbankan syariah memiliki pengaruh negatif terhadap return on asset dan profit sharing ratio yang bertolak belakang dengan teori legitimasi, ketika perusahaan melakukan kegiatan sosial akan berdampak pada image perusahaan yang dapat mendukung proses operasional perusahaan dan berdampak pada peningkatan laba perusahaan.

Namun seiiring dengan persaingan dan perkembangan dalam layanan perbankan, terutama perbankan syariah belum memberikan kontribusi yang maksimal dalam upaya mendukung penguatan keadilan sosial dan ekonomi, dengan kata lain aktivitas dan entitas sosial perbankan syariah belum maksimal (Nor, 2016). Dimana tanggungjawab sosial menjadi suatu gagasan bahwa perusahaan tidak lagi harus berurusan dengan tanggung jawab yang berpijak pada nilai perusahaan (corporate value) yang direfleksikan dalam kondisi keuangannya (financial) saja, tetapi tanggungjawabnya harus berpijak pada masalah sosial dan lingkungan.

Pertumbuhan bank syariah di Indonesia telah meningkat selama dekade terakhir dimana jumlah Bank Umum Syariah (BUS) yang terdaftar terbagi menjadi 14 BUS, 20 unit usaha Syariah dan 163 BPR Syariah dengan total 2.929 unit kantor di Indonesia. Total aset perbankan syariah sebesar 536,60 trilyun dan pangsa pasar 5,99\% dari perbankan nasional (Otoritas Jasa Keuangan, 2020). Sedangkan (Komite Nasional Keuangan Syariah, 2019) menyebutkan bahwa tumbuhnya aset perbankan syariah milik badan usaha milik negara (BUMN) sebesar 206,09 trilyun yang didalamnya terdapat BNI Syariah, Bank Syariah Mandiri, BRI Syariah dan BTN Syariah, dimana pada tahun 2020 diproyeksikan memperoleh CAGR senilai 1304,115 trilyun.

Fakta kinerja tanggungjawab sosial perbankan syariah menunjukkan sebagaimana yang diungkap (Abadi et al, 2020) bahwa pertama tema pendanaan dan investasi terdapat enam Bank Unit Syariah (BUS) yang kurang informatif, kedua pada tema produk dan jasa yang kurang informatif adalah BRI Syariah, ketiga pada tema karyawan terdapat lima BUS yang kurang informatif, keempat pada tema Masyarakat 


\section{Jurnal Ilmiah Ekonomi Islam, 6(03), 2020, 490}

terdapat enam BUS yang kurang informatif, dan kelima pada tema lingkungan terdapat sembilan BUS yang kurang informatif. Kemudian (Apip et al, 2016) mengungkapkan pengukuran Islamic Social Responsibility (ISR) bahwa Bank Syariah Mandiri berpredikat sangat informatif, sedangkan BRI Syariah berpredikat informatif dan BNI Syariah berpredikat tidak informatif. Sementara parameter lain menurut (Yusuf \& Bahari, 2015), yaitu enam kriteria dan tigapuluh empat item penting tanggungjawab sosial perusahaan yang berdampak pada masyarakat meliputi: ketaatan pada hukum Islam, kesetaraan, tanggungjawab pekerjaan, jaminan kesejahteraan, jaminan kelestarian lingkungan dan penggalangan kegiatan amal.

Pentingnya tanggungjawab sosial perbankan syariah perlu pengukuran atau parameter, salah satunya dengan Islamic Social Reporting (ISR) yang merupakan standar pengukuran atau pelaporan kinerja sosial perusahaan yang menggunakan prinsip syariah dan merupakan standar pelaporan kinerja sosial perusahaan perusaaan yang berbasis syariah. Indeks tersebut dikembangkan dari standar pelaporan berdasarkan Accounting and Auditing Organization for Islamic Financial Institutions (AAOIFI) yang kemudian dikembangkan oleh masing-masing (Haniffa, 2002; Trisnawati, 2012) yang menggunakan enam tema dan tigapuluh indikator. Selain itu secara khusus dalam indeks tersebut meliputi harapan masyarakat tidak hanya mengenai peran perusahaan dalam perekonomian, tetapi juga peran perusahaan dalam perspektif spiritual. Selain itu, indeks ini juga menekankan pada keadilan sosial terkait mengenai lingkungan, hak minoritas, dan karyawan (Mubarak et al, 2019).

Pentingnya untuk mengkaji penerapan tanggungjawab sosial pada perbankan syariah milik negara salah satunya memberikan informasi kepada publik dan stakeholder bahwa kepedulian perbankan syariah terhadap elemen lingkungan dan masyarakat memberikan makna. Apabila perbankan syariah milik pemerintah akan digabung atau merger tentunya akan memberi kontribusi yang lebih besar terhadap penerapan dan efektivitas tanggungjawab sosial perusahaan (CSR) mendatang termasuk dapat meningkatkan predikat semua dimensi pada tingkat sangat informatif yang berimplikasi pada penguatan kepercayaan stakeholder. Penguatan perbankan syariah di Indonesia perlu dilakukan secara berkelanjutan baik melalui pendekatan budaya, siklus bisnis dan kebijakan pemerintah, hal ini seiring isu penggabungan (merger) perbankan syariah yang bertujuan mencapai marketshare dan capital financing yang lebih maksimal sebagai upaya peningkatan dayasaing produk syariah di masa mendatang.

Dengan paparan yang telah disebutkan di atas, maka tujuan paper ini untuk mengetahui predikat dari penerapan tanggungjawab sosial perbankan syariah milik negara dengan pendekatan Islamic Social Reporting (ISR) indeks dengan enam dimensi meliputi pendanaan dan investasi, produk dan jasa, karyawan, masyaraat, lingkungan dan tata kelola perusahaan.

\section{METODOLOGI PENELITIAN}

Metode yang digunakan dalam penelitian ini adalah desktiptif dengan analisis kualitatif dan teknik Ethnographic Content Analysis (ECA). Data yang digunakan dalam penelitian ini adalah data sekunder bersumber dari laporan tahunan (annual report) bank syariah milik negara (BSMN) yang telah dipublikasikan di laman (webiste) resmi masingmasing perbankan syariah, Otoritas Jasa Keuangan dan Bank Indonesia.

Populasi penelitian ini adalah seluruh bank BUS di Indonesia, sedangkan sampel adalah bagian dari jumlah dan karakteristik yang dimiliki oleh populasi, sedangkan sampel dalam penelitian ini yaitu perusahaan atau perbankan syariah milik negara berdasarkan metode purposive sampling yaitu BNI Syariah, Bank Syariah Mandiri dan BRI Syariah sedangkan periode penelitian dibatasi dalam laporan periode 2014-2018. Teknik analisis data yang digunakan dalam penelitian ini adalah analisis data kualitatif (Sugiyono, 2014).

Adapun dimensi atau indikator yang digunakan untuk mengukur tanggungjawab sosial perbankan syariah menurut (Haniffa, 2002; Othman et al, 2009), yakni terdapat enam pengungkapan antara lain pendanaan dan investasi, produk dan jasa, tenaga kerja/laryawan, masyarakat, lingkungan hidup dan tata kelola perusahaan. Dalam komponen tersebut tedapat subtema ISR yang menjadi variabel operasional yang akan dilakukan skoring untuk setiap indikator sesuai laporan tahunan yang diteliti. Skor "1" diberikan untuk setiap subtema yang diungkapkan dan skor " 0 " diberikan untuk subtema yang tidak diungkapkan. Skor tertinggi jika seluruh subtema terpenuhi akan memperoleh angka "50". Setelah 
dilakukan skoring akan dinilai secara kumulatif berdasarkan rumus sebagai berikut:

Indeks ISR $=\frac{\text { Jumlah skor yang diungkapkan }}{\text { Jumlah skor maksimal }} \times 100 \%$

Setelah mendapatkan hasil kemudian menentukan predikat berdasarkan pendekatan yang digunakan, dimana skor pengungkapan diklasifikasikan dalam empat kategori atau predikat yaitu sangat informatif (81-100), informatif (66-81), kurang informatif (51-66) dan tidak informatf (0-51) (Gustani \& Bayinah, 2014).

\section{HASIL DAN PEMBAHASAN}

\subsection{Hasil}

\section{a. Tinjauan Perbankan Syariah Milik Negara}

Badan Usaha Milik Negara selanjutnya disebut BUMN yang telah diatur dalam undang-undang nomor 19 tahun 2003 yang menyebutkan bahwa BUMN adalah badan usaha yang seluruh atau sebagian besar modalnya dimiliki oleh negara melalui penyertaan langsung yang berasal dari kekayaan negara yang dipisahkan.

Sedangkan pada tahun 2008 pemerintah Indonesia telah mengeluarkan produk hukum yang berisi tentang perbankan syariag yaitu undang-undang nomor 21 tahun 2008 tentang perbankan syariah yang mana undang-undang ini mengatur hal yang berhubungan dengan aktivitas perbankan syariah termasuk didalamnya unit usaha syariah.

Dengan demikian sebuah badan usaha yang dapat dikategorikan sebuah BUMN jika modal badan usaha seluruhnya dimiliki oleh negara atau sebagian besar modalnya dimiliki oleh negara. Jika modal tersebut tidak dikuasai oleh negara, maka agar tetap dikategorikan sebagai BUMN, maka negara minimum menguasai $51 \%$ modal tersebut. Jika penyertaan modal negara di suatu badan usaha kurang dari $51 \%$ maka tidak dapat disebut sebagai sebuah BUMN (Ridwan, 2013).

Sementara itu (Nurma et al, 2016) berpendapat bahwa tujuan yang ingin dicapai dari undang-undang perbankan syariah antara lain untuk meningkatkan keadilan, kebersamaan dan pemerataan kesejahteraan rakyat. Salah satu yang diatur dalam undang-undang tersebut adalah kewajiban untuk melakukan pemisahan (spin off) yaitu apabila aset unit usaha syariah telah tercapai mencapai minimal $50 \%$ dari aset total bank induknya atau pemisahan wajib dilakukan maksimal pada tahun 2023 sebagaimana tercantum dalam undang-undang nomor 21 tahun 2008 tentang perbankan syariah.

Kebijakan tentang konsolidasi bertujuan untuk mendorong kemajuab perbankan syariah, dimana bank umum syariah hasil konsolidasi akan semakin kuat karena perusahaan semakin besar. Bank syariah BUMN akan memiliki kewenangan yaitu perbuatan hukum yang dilakukan oleh dua perseroan terbatas atau lebih sehingga menjadi status badan hukum, hal ini akan menjadi lebih kuat dan banyak manfaaatnya terkonsolidasi dibanding dengan bank syariah yang belum melakukan konsolidasi.

Dilain sisi unit usaha syariah yang dlakukan pemisahan akan membentuk bank umum syariah dimana bak umum syariah memiliki kewenangan yang lebih besar daripada unit syariah. Dengan adanya pemisahan yang telah dilakukan antara lain BNI Syariah, Bank Mandiri Syariah dan BRI Syariah. Adapun pembaharuan tersebut dilakukan oleh pemerintah untuk meningkatkan kesejahteraan masyarakat terutama dibidang perbankan, dimana otoritas jasa keuangan (OJK) mengambil kebijakan melakukan konsolidasi 3 (tiga) bank syariah yaitu BNI Syariah, Bank Syariah Mandiri dan BRI Syariah untuk membentuk bank umum syariah milik negara yang mana bank umum syariah ini akan memiliki status sebagai badan usaha milik negara dengan demikian (Azis, 2015) berpendapat bahwa pendirian bank berbasis syariah memiliki 2 (dua) tujuan yaitu untuk menghindari rba serta untuk berbagi resiko antara pihak perbankan dengan nasabahnya.

Dengan adanya perbankan syariah milik negara menjadi salah satu penguat perbankan syarah di Indonesia selain meningkatkan pangsa pasar dan aset yang penting lagi adalah kepercayaan, hal ini penting sebagai wujud menjalankan komintmen prinsip maqasid syariah sebagai motor dan pedoman perbankan syariah itu sendiri.

\section{b. Konsep Islamic Coorporate Social Responsibility (ICSR)}

Pengertian tanggungjawab sosial perusahaan (CSR) adalah pendekatan yang telah digunakan selama dua dekade oleh perusahaan untuk menunjukkan tanggung jawab perusahaan dalam pembangunan berkelanjutan. CSR ditemukan memiliki hubungan positif yang signifikan dengan kinerja keuangan perusahaan (Platonova et al. 2018). Namun penelitian sebelumnya mengungkapkan bahwa kegiatan CSR yang dilakukan oleh perusahaan 


\section{Jurnal Ilmiah Ekonomi Islam, 6(03), 2020, 492}

bukan murni niat. Namun CSR digunakan sebagai strategi bersaing perusahaan untuk membangun reputasi yang baik, menjaga kelangsungan bisnis, dan memaksimalkan keuntungan (Shim et al, 2017).

Tanggungjawab sosial perusahaan terhadap penerapan ICSR semakin menjadi isu penting dalam dunia bisnis. Dalam beberapa generasi sampai sekarang ini telah terlihat perubahan radikal dalam hubungan antara perusahaan dan masyarakat (Khursin, dkk, 2014) dengan demikian dalam merumuskan kebijakan dan praktik CSR, organisasi Islam harus membuat premis kebijakan dan praktik CSR yang melindungi Maqasid Syariah dengan lima elemen yang dilindungi yaitu iman, jiwa, akal, keturunan dan harta (Darus, 2014).

Dalam fakta lain menyebutkan bahwa tanggungjawab sosial secara islami menemukan efektivitas dewan direksi memainkan peran penting dalam menegakkan pengungkapan tanggung jawab sosial perusahaan. Sedangkan komite audit dan dewan pengawas syariah tidak berpengaruh signifikan terhadap pengungkapan tanggung jawab sosial perusahaan pada bank syariah (Ridwan \& Mayapada, 2020), sehingga pendapat (Hasan dan Harahap, 2010) sangat penting untuk menunjukkan akuntabilitas dan Islami pengambilan keputusan etis manajer, auditor dan anggota Dewan Pengawas Syariah tentang praktik pengungkapan CSR dalam laporan tahunan bank Islam. Pada literatur lain menunjukkan bahwa mayoritas negara maju, di mana pengungkapan tanggung jawab sosial merupakan praktik yang lebih umum, telah berfokus pada pelaporan CSR, dimana (Belal, 2008; Momin, 2006) menyatakan bahwa CSR di negara berkembang berada pada tahap awal dan eksplorasi. Sedangkan pada kasus di Malaysia (Jaiyeoba et al, 2018) mengungkapkan bahwa perbankan dan keuangan syariah telah muncul sebagai komponen penting dari keseluruhan sistem keuangan Malaysia yang berkontribusi pada pertumbuhan ekonomi Malaysia sehingga hasilnya menunjukkan bahwa pemangku kepentingan melihat CSR pada bank syariah di Malaysia sudah efektif.

Bank syariah juga harus memiliki aktivitas yang lebih besar terhadap CSR karena dipandu oleh prinsipprinsip agama atau etika yang kuat dan wajib mematuhi prinsip-prinsip Islam harus diterjemahkan ke dalam tindakan dan praktik aktual dalam aktivitas bank syariah, hal ini ditegaskan oleh (Basah \& Yusuf, 2013) jika tidak, prinsip dan pedoman seperti itu hanya menjadi teoretis. Pendapat lain bagaimana secara konsepsi (Hossain et al, 2013) berpendapat tanggung jawab perbankan Islam bahkan lebih tinggi daripada bank konvensional lainnya, karena Maqasid (tujuan) Bank Islam tidak hanya menyediakan layanan bebas bunga (seperti, halal Ayam) tetapi juga bertindak sebagai Khalifatullah (perwakilan Allah SWT) di dunia.

Salah satu reputasi dalam perbankan adalah evaluasi penilaian atas citra organisasi dari masyarakat, Islamic Corporate Social Responsibility (ICSR) adalah tanggung jawab sosial perusahaan yang berdimensi ekonomi dan islam, legal islam, etika islam dan filantropi islam berdasarkan nilai-nilai keislaman yang ada pada Al-Quran dan Hadist. Tujuan sistem bisnis Islam tidak terutama materialistis tetapi juga didasarkan pada konsep kesejahteraan manusia dan pencapaian keseluruhan kehidupan yang baik. Menurut (Carroll, 1979), mendefinisikan CSR berdasarkan operasi organisasi yang dilakukan untuk kepentingan masyarakat, karena tanggung jawab sosial bisnis mencakup ekspektasi ekonomi, hukum, etika, dan diskresi yang dimiliki masyarakat terhadap organisasi pada titik waktu tertentu. Kemudian (Longenecker et al, 2004) menunjukkan bahwa individu dengan orientasi keagamaan cenderung memiliki sikap yang berbeda terhadap CSR daripada mereka tanpa orientasi semacam itu. Selain itu, individu yang religius cenderung memiliki konsepsi yang lebih luas tentang tanggung jawab korporasi daripada individu yang tidak beragama. Memandang religiusitas (Conroy \& Emerson 2004) menemukan bahwa religiusitas memainkan peran penting dalam skenario etis. Bahkan, Menurut Angelidis dan Ibrahim (2004) berpendapat bahwa kelompok orang yang sangat religius memiliki keprihatinan yang lebih besar mengenai nilai etika CSR dan orientasi yang lebih lemah terhadap nilai ekonomi CSR. Demikian pula, (Dusuki \& Yusof , 2008) menemukan bahwa kelompok orang yang sangat religius memberikan nilai lebih pada dimensi hukum, etika dan filantropis dan kurang menekankan pada dimensi ekonomi dari model Carroll. Sebaliknya, (Agle \& Buren 1999) menemukan dukungan untuk hubungan antara religiusitas dan sikap positif terhadap CSR di mana mayoritas responden tidak percaya bahwa agama merupakan faktor yang mempengaruhi sikap mereka terhadap CSR.

Selain itu, beberapa penelitian telah menyimpulkan bahwa budaya juga memainkan peran penting dalam pengembangan CSR. Tanggung jawab 


\section{Jurnal Ilmiah Ekonomi Islam, 6(03), 2020, 493}

sosial perusahaan terhadap penerapan ICSR semakin menjadi isu penting dalam dunia bisnis. Dalam beberapa generasi sampai sekarang ini telah terlihat perubahan radikal dalam hubungan antara perusahaan dan masyarakat, salah satu kunci yang mendorong perubahan tersebut adalah isu mengenai pentingnya hubungan harmonis antara pihak pemegang saham atau stakeholders dan perusahaan, konsep ICSR terus menjadi topik yang hangat untuk didiskusikan didasari pada perspektif norma, budaya dan keyakinan. Kajian CSR dari sudut pandang islam (ICSR) yang dipraktikan di lembagaga keuangan syariah,akan memberikan nilai manfaat yang positif untuk diaplikasikan berdasarkan nila-nilai keuniversalan islam (Adnan dkk, 2014). Dimana aturan hukum dan moralitas dan aturan keadilan adalah dasar dari tanggung jawab sosial.

Dalam Islam, karakteristik tanggung jawab sosial sudah tertanam dalam Al-Qur'an dan Sunnah (Mohammed, 2007). Demikian pula, perusahaan dianggap memiliki tanggung jawab terhadap orang lain, termasuk masyarakat dan lingkungan, karena mereka adalah entitas yang memiliki hubungan dengan Tuhan, manusia lain dan pemangku kepentingan. Oleh karena itu, perusahaan diharuskan untuk memenuhi aturan dan peraturan Islam agar kegiatan mereka diberkati oleh Allah. Menurut etika Islam, perilaku, perbuatan, perkataan, perasaan, pikiran, dan niat umat Islam harus dipandu oleh nilainilai seperti kejujuran, kemanusiaan, dan penghormatan terhadap hukum. Islam meminta pengikutnya untuk mempertimbangkan norma dan kode moral tertentu dan untuk mengikuti aturan dan peraturan Islam dalam urusan keluarga mereka, transaksi bisnis, urusan sosial dan interaksi dengan orang lain.

Kepatuhan dengan perilaku etis adalah bagian dari dalam sistem bisnis Islam, tujuan utama tidak terutama materialistis tetapi didasarkan pada konsepkonsep kesejahteraan manusia dan pencapaian kehidupan yang baik. Islam menekankan nilai-nilai komunitas, keadilan sosial ekonomi dan keseimbangan antara kebutuhan material dan spiritual. Tanggung jawab filantropis Islam, islam memungkinkan pengikutnya untuk melakukan bisnis demi keuntungan tanpa merugikan orang lain atau lingkungan. Orang-orang diharapkan untuk menjamin keadilan bagi para pemangku kepentingan dan kesejahteraan bagi umat manusia. "Orang-orang diharapkan untuk menjamin keadilan bagi para pemangku kepentingan dan kesejahteraan bagi umat manusia" (QS.16: 90). Jelas dari berbagai sumber bahwa Islam mendukung setiap kegiatan yang ditujukan untuk kesejahteraan masyarakat. Penekanan pada keadilan dan keseimbangan dalam setiap bagian kehidupan secara jelas dinyatakan dalam Qur'an:masyarakat. Penekanan pada keadilan dan keseimbangan dalam setiap bagian kehidupan secara jelas dinyatakan dalam Qur'an: "Jadilah adil! Keadilan adalah yang terdekat dengan kesalehan "(QS.5:80). Pada kesempatan lain, Alquran menyatakan, "Jangan berurusan dengan tidak adil dan kamu tidak akan diperlakukan dengan tidak adil" (QS.2:279).

Ayat-ayat tersebut menyiratkan bahwa semua pemangku kepentingan menerima apa yang hanya untuk mereka, seperti pemegang saham, pelanggan berhak atas harga yang adil, kualitas barang dan pengungkapan informasi, dan karyawan berhak atas gaji yang tidak memadai, layanan kesehatan, pendidikan dan pembagian keuntungan. Islam juga mendorong orang untuk mengambil langkah-langkah yang tepat untuk memeriksa konsentrasi kekayaan ke dalam beberapa tangan, untuk mendistribusikan kembali sumber daya, untuk meminimalkan kesenjangan sosial dan untuk berbagi kekayaan kesehatan dengan orang-orang yang kurang beruntung dalam masyarakat dengan membayar zakat.

Dalam situasi terakhir ini, dimana pandemi Covid-19 melanda dunia dan mempengaruhi sendisendi kehidupan manusia, dengan kata lain, tingkat kebutuhan konsumen akan perilaku sosial dan aktualisasi diri yang lebih tinggi akan lebih dipenuhi oleh perilaku bertanggung jawab dan prososial mereka sebagai konsumen. Pandemi Covid-19 adalah peristiwa traumatis kolektif bagi banyak konsumen, menyebabkan mereka mengalami tekanan dan bahaya fisik, psikologis, dan emosional. (He \& Harris, 2020).Tetapi secara konsep dan sistem (Iskanda et al, 2020) mejelaskan bahwa penerapan konsep dan sistem ekonomi dan keuangan sosial Islam adalah: (1) dengan penyaluran bantuan langsung tunai yang berasal dari zakat, infak dan sedekah; (2) dengan penguatan wakaf baik berupa wakaf uang, wakaf produktif, waqf linked sukuk maupun wakaf untuk infrastruktur; (3) melalui bantuan modal usaha unggulan untuk sektor usaha atau Usaha Mikro Kecil Menengah (UMKM); (4) melalui skema qardhul hasan; (5) peningkatan literasi ekonomi dan keuangan 


\section{Jurnal Ilmiah Ekonomi Islam, 6(03), 2020, 494}

syariah; dan (6) melalui pengembangan teknologi finansial syariah.

Pemaparan di atas memberikan penjelasan bahwa penerapan tanggung jawab sosial secara islami pada perbankan syariah harus memenuhi konsep dan sistem yang ajaeg atau ketat hal ini sebagai panduan atau pedoman bagaimana penerapan yang dilakukan oleh perbankan syariah harus memprioritaskan prinsip syariah itu sendiri ternasuk fokus dan distribusi program yang dilaksanakan harus menganduk unsur keadilan dan kepedulian sosial.

\section{c. Konsep Indeks Islamic Social Responsibility (ISR) \\ Di Indonesia, pengungkapan (disclosure)} perbankan syariah secara umum telah terakomodasi dalam pernyataan standar akuntasi keuangan (PSAK) No.101 tahun 2006 tentang penyajian laporan keuangan syariah. Tetapi PSAK ini hanya berlaku untuk laporan keunagn dan tidak berlaku pada informasi lain yang disajikan dalam laporan tahunan sehingga terdapat variasi dikarenakan belum adanya standar khusus sebagai pedoman bagi penyeragaman laporan tersebut baik dari tema yang diungkapkan. tingkat pengungkapan, lokasi atau tempat pengungkapan dalam laporan tahunan dan tipe pengungkapan. Hal inilah yang memicu pemikiran tentang pentingnya Islamic Social Responsibility (ISR) indeks diterapkan pada perbankan syariah.

Konsep awal ISR diharapkan melahirkan konsep dan praktik akuntansi yang sesuai dengan syariat Islam sehingga dapat memberikan kontribusi kepada kemajuan ekonomi dan dan praktek bisnis sehingga dapat melebarkan praktek perdagangan yang lebih jujur, adil, bebas dari praktek bisnis internasional yang merusak tatana kehidupan manusia, maka dari itu perlunya konsep akuntabilitas sosial terkait dengan prinsip pengungkapan kebutuhan publik akan suatu informasi berdasarkan prinsip syariah. Adapun penjabaran dimensi atau teman dan indikator atau subtema sebagaimana pada tabel 1 .

d. Penerapan Tanggungjawab Sosial Perbankan Syariah berdasarkan Indeks ISR

Tabel 1. Islamic Sosial Responsibility (ISR) Index

\begin{tabular}{|c|l|l|}
\hline NO & $\begin{array}{c}\text { DIMENSI/ } \\
\text { TEMA }\end{array}$ & \multicolumn{1}{c|}{ INDIKATOR/SUBTEMA } \\
\hline 1. & $\begin{array}{l}\text { Pendanaan } \\
\text { dan Investasi }\end{array}$ & $\begin{array}{l}\text { Identifikasi yang mengandung riba, identifikasi yang mengandung gharar, sumber dan } \\
\text { jumlah zakat serta metode pengumpulan dan distribusi zakat, serta kebijakan mengatasi } \\
\text { keterlambatan pembayaran }\end{array}$ \\
\hline 2. & Prioduk Jasa & $\begin{array}{l}\text { Status halal dalam produk, pengembangan produk, peningkatan pelayanan dan keluhan } \\
\text { pelanggan }\end{array}$ \\
\hline 3. & Karyawan & $\begin{array}{l}\text { Karakteristik pekerjaan, pendidikan dan pelatihan, kesempatan yang sama, kesehatan } \\
\text { dan keselamatan kerja, lingkungan kerja dan perekrutan khusus. }\end{array}$ \\
\hline 4. & Masyarakat & $\begin{array}{l}\text { Penyaluran dan distribusi zakat, donasi, qardul hasan, zakat atau sumbangan yang } \\
\text { berasal dari karyawan, nasabah dan umum, kepedulian anak yatim, pembangunan atau } \\
\text { renovasi sarana ibadah, kegiatan pemuda dan kemasyarakatan, kegiatan sosial dan } \\
\text { sponsor acara kesehatan }\end{array}$ \\
\hline 5. & Lingkungan & $\begin{array}{l}\text { Kampanye dan pelaksanaan go green, konservasi lingkungan, perlindungan terhadap } \\
\text { flora dan fauna, tingkat polusi, perbaian dan pembuatan sarana umum, audit } \\
\text { lingkungan dan kebijakan manajemen lingkungan }\end{array}$ \\
\hline 6. & $\begin{array}{l}\text { Tata Kelola } \\
\text { Perusahaan }\end{array}$ & $\begin{array}{l}\text { Profil dan strategi organisasi, struktur organisasi, pelaksanaan tugas dan tanggung } \\
\text { jawab dewan komisaris, pelaksanaan dan tanggung jawab dewan direksi, kelengkapan } \\
\text { dan pelaksanaan tugas komite, pelaksanaan dan tanggungjawab dewan pengawas } \\
\text { syariah, pelaksanaan prinsip syariah dalam, perhimpunan dan penyaluran dana serta } \\
\text { pelayanan jasa, penanganan antar kepentingan, penerapan fungsi kepatuhan bank, } \\
\text { penerapan fungsi audit intern, penerapan fungsi audit ekstrernal, batas maksimum } \\
\text { penyaluran dana, transparansi kondisi keuangan dan non keuangan, kebijakan anti cuci } \\
\text { uang dan praktek menyimpang lainnya, dan etika perusahaan }\end{array}$ \\
\hline
\end{tabular}

(Sumber: Haniffa, 2002: Othman, et al, 2010 \& Trisnawati, 2012, diolah, 2020) 
Dalam pembahasan ini akan dilakukan analisis terhadap 6 (enam) dimensi atau tema yang ada pada indeks ISR yang terdiri dari 50 sub tema dari tahun 2014-2018 pada perbankan syariah milik pemerintah. Tingkat atau predikat penerapan pelaporan sosial ditentukan seberapa banyak perbankan syariah memenuhi sub tema yang ada dalam indeks ISR, semakin banyak yang terpenuhi maka tanggungjawaba sosial perbankan syaria akan semakin baik.

\section{1) Dimensi Pendanaan dan Investasi}

Pada dimensi pendanaan dan investasi terdapat enam subtema atau indikator penilaian tanggungjawab sosial yaitu identifikasi yang mengandung riba, identifikasi yang mengandung gharar, sumber dan jumlah zakat serta metode pengumpulan dan distribusi zakat, serta kebijakan mengatasi keterlambatan pembayaran. Berdasarkan hasil skoring indeks ISR dimensi pendanaan dan investasi periode 2014-2018 diperoleh rata-rata indeks ISR setiap perbankan syariah milik negara ditunjukkan dalam tabel 2 .

Tabel 2. Rata-Rata Indeks ISR Perbankan

Syariah Milik Negara Periode 2014-2018 (Pendanaan dan Investasi)

\begin{tabular}{|c|r|r|r|r|r|r|}
\hline $\begin{array}{c}\text { Bank/ } \\
\text { Thn }\end{array}$ & 2014 & 2015 & 2016 & 2017 & 2018 & Rata2 \\
\hline BNIS & 66,67 & 66,67 & 83,33 & 66,67 & 83,33 & 73,33 \\
\hline BSM & 50 & 50 & 100 & 66,67 & 50 & 63,33 \\
\hline BRIS & 66.67 & 66,67 & 83,33 & 50 & 83,33 & 56,67 \\
\hline Rata2 & 38,89 & 61,11 & 88,89 & 61,11 & 72,22 & 68,89 \\
\hline
\end{tabular}

(Sumber: annual report perbankan syariah, data diolah, 2020)

Data tabel 2 menunjukkan bahwa ketiga perbankan syariah milik negara tersebut memperoleh predikat tanggungjawab sosial diatas 50, dimana BNI Syariah mendapat 73,73 dan BSM mendapat 63,33 dengan predikat informatif sedangkan BRI Syariah mendapat 56,67 dengan predikat kurang informatif sehingga rata-rata diperoleh sebesar 68,89 dengan predikat informatif.

2) Dimensi Produk dan Jasa

Pada dimensi produk dan jasa terdapat empat subtema yang menjadi indikator penilaian dalam Indeks ISR yakni status halal dalam produk, pengembangan produk, peningkatan pelayanan dan keluhan pelanggan. Berdasarkan hasil skoring indeks ISR dimensi produk dan jasa periode 2014-2018 diperoleh rata-rata indeks ISR setiap perbankan syariah milik negara ditunjukan dalam tabel 3 .
Tabel 3. Rata-Rata Indeks ISR Perbankan

Syariah Milik Negara Periode 2014-2018

(Produk dan Jasa)

\begin{tabular}{|c|c|c|c|c|c|c|}
\hline $\begin{array}{c}\text { Bank/ } \\
\text { Thn }\end{array}$ & 2014 & 2015 & 2016 & 2017 & 2018 & Rata2 \\
\hline BNIS & 100 & 100 & 100 & 100 & 100 & 100,00 \\
\hline BSM & 100 & 100 & 100 & 0 & 100 & 80,00 \\
\hline BRIS & 33,33 & 33,33 & 100 & 100 & 100 & 73,33 \\
\hline Rata2 & 77,78 & 77,78 & 100,00 & 66,67 & 100,00 & 91,11 \\
\hline
\end{tabular}

(Sumber: annual report perbankan syariah, data diolah, 2020)

Dari tabel 3 dapat dijelaskan bahwa ketiga perbankan syariah milik negara tersebut memperoleh predikat tanggungjawab sosial diatas 50, dimana BNI Syariah mendapat 100 dan BSM mendapat 80,33 dengan predikat sangat informatif sedangkan BRI Syariah mendapat 73,33 dengan predikat informatif sehingga rata-rata diperoleh sebesar 91,11 dengan predikat sangat informatif.

3) Dimensi Karyawan

Pada dimensi karyawan terdapat enam subtema yang menjadi indikator penilaian dalam Indeks ISR yakni karakteristik pekerjaan, pendidikan dan pelatihan, kesempatan yang sama, kesehatan dan keselamatan kerja, lingkungan kerja dan perekrutan khusus. Berdasarkan hasil skoring indeks ISR dimensi produk dan jasa periode 2014-2018 diperoleh rata-rata indeks ISR setiap perbankan syariah milik negara ditunjukan dalam tabel 4.

Tabel 4. Rata-Rata Indeks ISR Perbankan Syariah Milik Negara Periode 2014-2018 (Karyawan)

\begin{tabular}{|c|c|c|c|c|c|c|}
\hline $\begin{array}{c}\text { Bank/ } \\
\text { Thn }\end{array}$ & 2014 & 2015 & 2016 & 2017 & 2018 & Rata2 \\
\hline BNIS & 69,23 & 69,23 & 84,62 & 76,92 & 56,41 & 71,28 \\
\hline BSM & 61,54 & 84,62 & 61,54 & 84,62 & 76,92 & 73,85 \\
\hline BRIS & 38,46 & 61,54 & 71,8 & 79,49 & 84,62 & 67,18 \\
\hline Rata2 & 56,41 & 71,80 & 72,65 & 80,34 & 72,65 & 68,72 \\
\hline
\end{tabular}

(Sumber: annual report perbankan syariah, data diolah, 2020)

Data tabel 4 menunjukkan bahwa ketiga perbankan syariah milik negara tersebut memperoleh predikat tanggungjawab sosial diatas 50, dimana BNI Syariah mendapat 71,28 dan BSM mendapat 73,85 serta BRI Syariah mendapat 67,18 dengan predikat informatif sehingga rata-rata diperoleh sebesar 68,72 dengan predikat informatif. 
4) Dimensi Masyarakat

Pada dimensi masyarakat terdapat dua belas subtema yang menjadi indikator penilaian dalam Indeks ISR yakni penyaluran dan distribusi zakat, donasi, qardul hasan, zakat atau sumbangan yang berasal dari karyawan, nasabah dan umum, kepedulian anak yatim, pembangunan atau renovasi sarana ibadah, kegiatan pemuda dan kemasyarakatan, kegiatan sosial dan sponsor acara kesehatan. Berdasarkan hasil skoring indeks ISR dimensi produk dan jasa periode 2014-2018 diperoleh rata-rata indeks ISR setiap perbankan syariah milik negara ditunjukan dalam tabel 5 .

Tabel 5. Rata-Rata Indeks ISR Perbankan Syariah Milik Negara Periode 2014-2018 (Masyarakat)

\begin{tabular}{|c|c|c|c|c|c|c|}
\hline $\begin{array}{c}\text { Bank/ } \\
\text { Thn }\end{array}$ & 2014 & 2015 & 2016 & 2017 & 2018 & Rata2 \\
\hline BNIS & 81,82 & 63,64 & 90,91 & 81,82 & 81,82 & 80,00 \\
\hline BSM & 63,64 & 72,73 & 81,82 & 81,82 & 90,91 & 78,18 \\
\hline BRIS & 36,36 & 63,64 & 54,55 & 81,82 & 100 & 67,27 \\
\hline Rata2 & 60,61 & 66,67 & 75,76 & 81,82 & 90,91 & 75,15 \\
\hline
\end{tabular}

(Sumber: annual report perbankan syariah, data diolah, 2020)

Data tabel 5 menunjukkan bahwa ketiga perbankan syariah milik negara tersebut memperoleh predikat tanggungjawab sosial diatas 50, dimana BNI Syariah mendapat 80 dengan predikat sangat informatif, BSM mendapat 78,18 dan BRI Syariah mendapat 67,81 dengan predikat informatif sehingga rata-rata diperoleh sebesar 75,15 dengan predikat informatif.

5) Dimensi Lingkungan

Pada dimensi lingkungan terdapat tujuh subtema yaitu kampanye dan pelaksanaan go greeb, konservasi lingkungan, perlindungan terhadap flora dan fauna, tingkat polusi, perbaian dan pembuatan sarana umum, audit lingkungan dan kebijakan manajemen lingkungan. Berdasarkan hasil skoring indeks ISR dimensi produk dan jasa periode 2014-2018 diperoleh rata-rata indeks ISR setiap perbankan syariah milik negara ditunjukan dalam tabel 6 .

Tabel 6. Rata-Rata Indeks ISR Perbankan Syariah Milik Negara Periode 2014-2018 (Lingkungan)

\begin{tabular}{|c|c|c|c|c|c|c|}
\hline $\begin{array}{c}\text { Bank/ } \\
\text { Thn }\end{array}$ & 2014 & 2015 & 2016 & 2017 & 2018 & Rata2 \\
\hline BNIS & 0 & 0 & 60 & 60 & 80 & 40,00 \\
\hline BSM & 40 & 40 & 40 & 60 & 40 & 44,00 \\
\hline BRIS & 40 & 20 & 80 & 60 & 80 & 56,00 \\
\hline Rata2 & 26,67 & 20,00 & 60,00 & 60,00 & 66,67 & 46,67 \\
\hline
\end{tabular}

(Sumber: annual report perbankan syariah, data diolah, 2020)
Data tabel 6 menunjukkan bahwa semua perbankan syariah milik negara memperoleh predikat tanggungjawab sosial dibawah 60, dimana BNI Syariah mendapat 40 dan BSM mendapat 40 dengan predikat tidak informatif sedangkan BRI Syariah mendapat 56 dengan predikat kurang informatif sehingga rata-rata diperoleh sebesar 46,67 dengan tidak informatif.

6) Dimensi Tata Kelola Perusahaan

Pada dimensi tata kelola perusahaan terdapat lima belas subtema yaitu profil dan strategi organisasi, struktur organisasi, pelaksanaan tugas dan tanggung jawab dewan komisaris, pelaksanaan dan tanggung jawab dewan direksi, kelengkapan dan pelaksanaan tugas komite, pelaksanaan dan tanggungjawab dewan pengawas syariah, pelaksanaan prinsip syariah dalam, perhimpunan dan penyaluran dana serta pelayanan jasa, penanganan antar kepentingan, penerapan fungsi kepatuhan bank, penerapan fungsi audit intern, penerapan fungsi audit ekstrernal, batas maksimum penyaluran dana, transparansi kondisi keuangan dan non keuangan, kebijakan anti cuci uang dan praktek menyimpang lainnya, dan etika perusahaan. Berdasarkan hasil skoring indeks ISR dimensi produk dan jasa periode 2014-2018 diperoleh rata-rata indeks ISR setiap perbankan syariah milik negara ditunjukan dalam tabel 7.

Tabel 7. Rata-Rata Indeks ISR Perbankan

Syariah Milik Negara Periode 2014-2018 (Tata Kelola Perusahaan)

\begin{tabular}{|l|r|r|r|r|r|r|}
\hline $\begin{array}{c}\text { Bank } \\
\text { / Thn }\end{array}$ & 2014 & 2015 & 2016 & 2017 & 2018 & Rata2 \\
\hline BNIS & 93 & 93,33 & 100 & 100 & 100 & 97,27 \\
\hline BSM & 100 & 100 & 100 & 100 & 100 & 100,00 \\
\hline BRIS & 80 & 86,67 & 100 & 66,67 & 100 & 86,67 \\
\hline Rata2 & 91,00 & 93,33 & 100,00 & 88,89 & 100,00 & 84,44 \\
\hline
\end{tabular}

(Sumber: annual report perbankan syariah, data diolah, 2020)

Data tabel 7 menunjukkan bahwa ketiga perbankan syariah milik negara tersebut memperoleh predikat tanggungjawab sosial di atas 50, dimana BNI Syariah mendapat 97,27 dan BSM mendapat 100 serta BRI Syariah mendapat 86,67 dengan predikat sangat informatif sehingga rata-rata diperoleh sebesar 88,44 dengan predikat sangat informatif. 
Secara keseluruhan penerapan tanggungjawab sosial perbankan syariah milik negara dari tahun 2014-2018 terdapat pada tabel 8.

Tabel 8. Rata-Rata Kumulatif Indeks ISR Perbankan Syariah Milik Negara Periode 2014-2018

\begin{tabular}{|c|l|r|r|r|r|r|r|}
\hline No & Dimensi/ Tema & $\mathbf{2 0 1 4}$ & $\mathbf{2 0 1 5}$ & $\mathbf{2 0 1 6}$ & $\mathbf{2 0 1 7}$ & $\mathbf{2 0 1 8}$ & \multicolumn{1}{|c|}{ Rata2 } \\
\hline 1 & Pendanaan \& Investasi & $61,11 \%$ & $61,11 \%$ & $88,89 \%$ & $61,11 \%$ & $72,22 \%$ & $68,89 \%$ \\
\hline 2 & Produk \& Jasa & $77,78 \%$ & $77,78 \%$ & $100,00 \%$ & $100,00 \%$ & $100,00 \%$ & $91,11 \%$ \\
\hline 3 & Karyawan & $56,41 \%$ & $71,80 \%$ & $79,49 \%$ & $56,41 \%$ & $79,49 \%$ & $68,72 \%$ \\
\hline 4 & Masyarakat & $60,61 \%$ & $66,67 \%$ & $75,76 \%$ & $81,82 \%$ & $90,91 \%$ & $75,15 \%$ \\
\hline 5 & Lingkungan & $26,67 \%$ & $20,00 \%$ & $60,00 \%$ & $60,00 \%$ & $66,67 \%$ & $46,67 \%$ \\
\hline 6 & Tata Kelola Perusahaan & $60,00 \%$ & $93,33 \%$ & $100,00 \%$ & $88,89 \%$ & $100,00 \%$ & $88,44 \%$ \\
\hline
\end{tabular}

(Sumber: annual report perbankan syariah, data diolah, 2020)

Data dalam tabel tersebut menunjukkan bahwa ketiga perbankan syariah milik negara memperoleh predikat tanggungjawab sosial di atas 50 kecuali dimensi lingkungan, dimana pendanaan dan ivestasi mendapat 68,89 dengan predikat informatif, produk dan jasa mendapat 91,11 dengan predikat sangat informatif, karyawan mendapat 68,72 dengan predikat informatif, masyarakat mendapat 75,15 dengan predikat informatif, lingkungan mendapat 46,67 dengan predikat kurang informatif dan tata kelola perusahaan mendapat 88,44 dengan predikat sangat informatif, sehingga secara keseluruh dapat diungkap bahwa tanggungjawab sosial perbankan syariah milik negara tahun 2014-2018 diperoleh sebesar 73,16 dengan predikat informatif.

Tabel 9. Rata-Rata Indeks ISR berdasarkan Urutan Predikat Perbankan Syariah

\begin{tabular}{|c|c|c|c|c|c|c|}
\hline $\begin{array}{c}\text { Bank/ } \\
\text { Thn }\end{array}$ & 2014 & 2015 & 2016 & 2017 & 2018 & Rata2 \\
\hline BNIS & $52,95 \%$ & $65,48 \%$ & $85,19 \%$ & $80,90 \%$ & $87,01 \%$ & $74,31 \%$ \\
\hline BSM & $69,20 \%$ & $74,56 \%$ & $83,12 \%$ & $79,62 \%$ & $77,59 \%$ & $76,82 \%$ \\
\hline BRIS & $49,14 \%$ & $55,31 \%$ & $83,75 \%$ & $63,60 \%$ & $90,04 \%$ & $68,37 \%$ \\
\hline
\end{tabular}

(Sumber: annual report perbankan syariah, data diolah, 2020)

Dari perbandingan tabel 9 di atas menunjukkan bahwa predikat penerapan tanggung jawab sosial perbankan syariah dengan predikat paling baik secara berurutan adalah pertama BSM sebesar 76,82 dan kedua BNI Syariah sebesar 74,31 serta ketiga BRI Syariah sebesar 68,37 seluruhnya memiliki predikat informatif.

\subsection{PEMBAHASAN}

Hal ini menegaskan bahwa penerapan tanggungjawab sosial pada perbankan syariah belum optimal karena baru sebatas informatif sehingga hasil ini didukung oleh literatur yang ada menunjukkan bahwa mayoritas negara maju, di mana pengungkapan tanggung jawab sosial merupakan praktik yang lebih umum, telah berfokus pada pelaporan CSR. Kemudian (Belal, 2008; Momin, 2006) menyatakan bahwa CSR di negara berkembang berada pada tahap awal dan eksplorasi serta (Arif \& Zaki, 2017) menjelaskan bahwa tingkat pengungkapan informasi sosial berdasarkan indeks ISR masih belum optimal, hal ini dapat dilihat dari nilai rataratanya sebesar 46,39\% begitu juga (Gustani, 2013) dengan judul analisis tingkat pengungkapan kinerja sosial bank syariah berdasarkan Islamic Social Reporting Index (ISR Indeks) secara keseluruhan menunjukkan bahwa pengungkapan kinerja sosial bank umum syariah di Indonesia masih kurang informatif atau kurang baik.

Kemudian (Trisnawati, 2012) menunjukkan bahwa pengungkapan CSR pada bank syariah di Indonesia dengan indeks ISR $(48.75 \%)$ lebih baik dibandingkan dengan indeks GRI (21.54\%), walaupun (Wulandari, 2016) menunjukkan bahwa pengungkapan kinerja sosial bank umum syariah di Indonesia mengalami peningkatan dari tahun ke tahun. Penelitian ini dilakukan dalam rentang waktu 2014-2016. Kemudian pada tahun 2015-2017 penilaian indeks ISR pada bank umum syariah dari menunjukkan bahwa tingkat pengungkapan kinerja sosial 12 Bank Umum Syariah di Indonesia mendapatkan predikat baik seacara rata rata, dan terus mengalami peningkatan dari tahun ke tahun untuk 


\section{Jurnal Ilmiah Ekonomi Islam, 6(03), 2020, 498}

optimalisasi sumber daya yang dimiliki untuk terus memperhatikan kegiatan kegiatan sosial (Mubarok \& Bayinah, 2019).

Adapun keterbatasan dalam paper ini yaitu jumlah periode pengamatan masih singkat sehingga masih kurang bisa menggambarkan kondisi pelaporan sosial atau tanggung jawab sosial perbankan syariah milik negara secara utuh dan pelaporan tanggung jawab sosial menggunakan indek ISR tidak memperhatikan jumlah subtema/indikator melainkan jika sudah ada satu subtema yang dilaksanakan maka dianggap sudah melaksanakan tanggung jawab sosial.

\section{KESIMPULAN}

Perbankan syariah milik negara memperoleh predikat penerapan tanggungjawab sosial di atas 50 kecuali dimensi/tema lingkungan, dimana pendanaan dan ivestasi berpredikat informatif, produk dan jasa mendapat berpredikat sangat informatif, karyawan berpredikat informatif, masyarakat berpredikat informatif, lingkungan berpredikat kurang informatif dan tata kelola perusahaan berpredikat sangat informatif, secara keseluruhan penerapan tanggungjawab sosial perbankan syariah milik negara tahun 2014-2018 berpredikat informatif dengan urutan BSM, BNI Syariah dan BRI Syariah.

\section{REFERENSI}

Abadi Muhammad Taufiq, Muhammad Sultan Mubarok, dan Ria Anisatus Sholihah (2020). Implementasi Islamic Social Reporting Index Sebagai Indikator Akuntabilitas Sosial Bank Syariah. Jurnal Al-Insyiroh: Jurnal Studi Keislaman, 6(1), pp.1-25।

Al-Qur'an Terjemahan (2015). Departemen Agama RI. Bandung: CV. Darus Sunnah

Ang Swat Lin Lindawati dan Marsella Eka Puspita (2015). Corporate Social Responsibility: Implikasi Stakeholder dan Legitimacy Gap Dalam Peningkatan Kinerja Perusahaan. Jurnal Akuntansi Multiparadigma JAMAL, 6(1), pp.117

Apip Zanariyatim, Ai Nur Bayinah dan Oni Sahroni (2018). Pengungkapan Corporate Social Responsibility (CSR) Bank Umum Syariah Berdasarkan Islamic Social Reporting Index (Indeks ISR). Jurnal Akuntansi dan Keuangan Islam, 4(1), pp.85-104
Arif Budimanta (et al). (2004). Corporate Social Responsibility Jawaban dari Pembangunan Indonesia Masa Kini. Jakarta: Indonesian Center for Sustainable Development (ICSD).

Arif Lukman Santoso dan Zaki Murtadho DhiyaulHaq (2017). Determinan Pengungkapan Islamic Social Reporting pada Bank Umum Syariah di Indonesia. Jurnal Dinamika Akuntansi dan Bisnis, 4(2), pp.125-142

Aziz Budi Setiawan, (2015). Perbankan Syariah: Challenges dan Opportunity Untuk Pengembangan di Indonesia. Jurnal Kordinat 8 (1), pp.23-34

Azlan Amran, Hasan Fauzi, Yadi Purwanto, Faizah Darus, Haslinda Yusoff, Mustaffa Mohamed Zain, Dayang Milianna Abang Naim, and Mehran Nejati (2017). Social Responsibility Disclosure in Islamic Banks: a Comparative Study of Indonesia and Malaysia. Journal of Financial Reporting and Accounting,15(1), pp.99-115

Azwar Iskanda, Bayu Taufiq Possumah, and Khaerul Aqbar (2020). Peran Ekonomi dan Keuangan Sosial Islam Saat Pandemi Covid-19. Jurnal Sosial \& Budaya Syar'i FSH UIN Syarif Hidayatullah Jakarta, 7(7), pp.625-638

Basah Mohamad Yazis Ali and Mazlynda Md Yusuf (2013). Islamic Bank and Corporate Social Responsibility (CSR). EJBM-Special Issue: Islamic Management and Business, 5(11), pp.194-209

Belal, A.R. (2008). Corporate Social Responsibility Reporting in Developing Countries: The Case of Bangladesh. Ashgate: Aldershot.

Budi Gautama Siregar (2015). Penerapan Corporate Social Responsibility (CSR) Dalam Pandangan Islam. JURIS, 14(2), pp.136-150.

Darus Faizah, Haslinda Yusoff, Dayang Milianna Abang Naim, Mustaffa Mohamed Zain, Azlan Amran, Hasan Fauzi, and Yadi Purwanto (2013). Islamic Corporate Social Responsibility (ICSR) Framework from the Perspective of Maqasid alSyariah and Maslahah. Issues in Social and Environmental Accounting, 7(2), pp.102-112

Diesendorf, M. (2000). Sustainability and Sustainable Development.

In D.Dunphy, J.Benveniste, A.Griffiths, \& P.Sutton (Eds.), Sustainability: The Corporate Challenge Of The 21st Century. Sydney: Allen \& Unwin. 


\section{Jurnal Ilmiah Ekonomi Islam, 6(03), 2020, 499}

Diyah Pujiati (2017). Corporate Social Responsibility Factors at Sharia Banks in Indonesia. International Journal of Economic Research, 14(15), pp.221-227

Elena Platonova, Mehmet Asutay, Rob Dixon, and Sabri Mohammad (2018). The Impact of Corporate Social Responsibility Disclosure on Financial Performance: Evidence from the GCC Islamic Banking Sector. Journal Bussiness Ethics 151, pp.451-471

Gustani, \& Bayinah, A.N. (2014). Model Pelaporan Kinerja Sosial Perbankan Syariah : Implementasi Islamic Social Reporting Index (Index ISR) di Indonesia. Jurnal Akuntansi dan Keuangan Islam , 2 (1), pp.35-46

Hadinata Sofyan (2018). Islamic Social Reporting Index dan Kinerja Keuangan Pada Perbankan Syariah di Indonesia. EkBis: Jurnal Ekonomi dan Bisnis, 2(1), pp.72-95

Haniffa, R. (2002). Social Reporting Disclosure-An Islam Prespektif. Indonesian Management \& Accounting Research, 1(2), pp.128-146.

Hassan, A. and Harahap, S.S. (2010). Exploring Corporate Social Responsibility Disclosure: The Case of Islamic Banks, International Journal of Islamic and Middle Eastern Finance and Management, 3(3), pp.203-227

He Hongwei and Lloyd Harris (2020). The impact of Covid-19 Pandemic on Corporate Social Responsibility and Marketing Philosophy. Journal of Business Research, 116, pp.176-182

Hossain Md. Tareq, Chamhuri Siwar and Abdul Razak Omar (2013). Corporate Social Responsibility as A Mean to Mitigate Risk for Islamic Banking Industry. International Conference on Business Inovation, Enterpreneur and Engginering (ICOBIEE), pp.123-127

Jaiyeoba Haruna Babatunde, Abideen Adeyemi Adewale and Mahmud Oluwaseyi Quadry (2018). Are Malaysian Islamic Banks Corporate Social and Responsibilities Effective? A Stakeholders View. International Journal of Bank Marketing (IJBM), 36(1), pp.111-125

James Brusseau (2012). The Business Ethics Workshop. Washington DC: Saylor Foundation

Khurshid, Muhammad Adnan, Abdulrahmman AlAali, Ahmed Ali Soliman and Salmiah Muhd Amin. (2014). Developing an Islamic Corporate Social Responsibility Model (ICSR) Corporate Social Responsibility (CSR), Islamic CSR Model (ICSR). Journal of Islamic Principles 24 (4), pp.258-274
Komite Nasional Keuangan Syariah (2019). Kajian Konvergensi, Merger, Holding, dan Pembentukan Bank BUMN Syariah: Sebagai Penguatan dari Program Penguatan Bank Syariah. Jakarta: Komite Nasional Keuangan Syariah. Diakses dari www.knks.go.id

Maesya'bani, Sri Mulyati dan Erina Maulidha (2019). Pengungkapan Tanggung Jawab Sosial Perbankan Syariah Di Asia Tenggara Berdasarkan Indeks Islamic Social Reporting. Jurnal Akuntansi dan Keuangan Islam, 7(1), pp.23-36

Meshaal J. Alshammary (2014). Islamic Corporate Social Responsibility (ICSR) Concept: The Case of 21st Century Middle East. Corporate Board: Role, Duties \& Composition, 10(2), pp.64-74

Meutia, I. (2009). Sharia Enterprise Theory Sebagai Dasar Pengungkapan Tanggung Jawab Sosial Bank Syariah.. Disertasi Ilmu Akuntasi Universitas Brawijaya. Malang.

Momin, M.A. (2006). Corporate Social Responsibility and Reporting by Multinational Corporations in Bangladesh-an exploration, PhD thesis, University of Glasgow, Glasgow.

Mubarak Darihan, Sigit Pramono dan Ai Nur Bayinah (2019). Pengungkapan Kinerja Sosial Perbankan Syariah di Indonesia Menggunakan Islamic Social Reporting Index. Jurnal Akuntansi dan Keuangan Islam 7(1), pp.37-58.

Nor, S. M. (2016). Islamic Social Bank : An Adaption of Islamic Banking?. Jurnal Pengurusan, 46(1), pp.4-6

Nurma Gupitasari, Rofah Setyowati, dan Muhyidin (2016). Mekanisme Konsolidasi Bank Syariah Anak Perusahaan Badan Usaha Milik Negara (BUMN) Dari Perspektif Yuridis. Diponegoro Law Journal 5(3), pp.1-22

Otoritas Jasa Keuangan (2020). Snapshot Perbankan Syariah Indonesia: Posisi Maret 2020. Jakarta: Otoritas Jasa Keuangan. Diakses dari www.ojk.go.id

PewResearch Center (2009). Mapping the Global Muslim Population, Posted on: October 7, 2009, Diakses

dari www.pewforum.org/2009/10/07/mapping-theglobal-muslim-population. .

Putri Nurul Wulandari (2019). Implementasi Penerapan Islamic Corporate Social Responsibility Pada Spiritual Company Waroeng Group Perspektif Maqasid Al-Syariah. Jurnal Valid, 16(2), pp.208-214 
Quazi, A., Nejati, M. and Amran, A. (2015). The CSR Journey: Looking Through The Evolutionary Lens", in Nejati, M., Quazi, A. and Amran, A. (Eds), Corporate Social Responsibility and Sustainability: Contemporary Perspectives. Kuala Lumpur: Pearson

Rice Gillian, (1999). Islamic Ethics and the Implications for Business. Journal of Business Ethics, 18, pp.345-358

Ridwan Khairandy, (2013). Pokok-Pokok Hukum Dagang, Yogyakarta: FHUII Press.

Ridwan Ridwan and Arung Gihna Mayapada (2020). Does Sharia Governance Influence Corporate Social Responsibility Disclosure in Indonesia Islamic Banks?. Journal of Sustainable Finance \& Investment, Taylor \& Francis, pp.1-17.

Shim, K., Chung, M., \& Kim, Y. (2017). Does Ethical Orientation Matter? Determinants of Public Reaction to CSR Communication. Public Relations Review, 43(4), pp.817-828
Sofyani, Hafiez, Ihyaul Ulum, Daniel Syam, dan Sri Wahjuni. (2012). Islamic Social Reporting Indeks sebagai Model Pengukuran Kinerja Sosial Perbankan Syariah (Studi Komparasi Indonesia dan Malaysia). Jurnal Dinamika Akuntansi,4(1), pp.36-46.

Sugiyono. (2014). Memahami Penelitian Kualitatif. Bandung: Alfabeta

Trisnawati Rina (2012). Pengukuran Tanggung Jawab Sosial Perusahaan Perbankan Syariah di Indonesia. JAAI, 16(2), pp.103-121.

Yusuf Muhammad Yasir and Zakaria bin Bahari (2015). Islamic. Corporate Social Responsibility in Islamic Banking: Towards Poverty Alleviation. Ethics, Governance and Regulation in Islamic Finance, 8th International Conference on Islamic Economics and Finance, pp.73-89. 